\title{
Root Growth and Enzymes Related to the Lignification of Maize Seedlings Exposed to the Allelochemical L-DOPA
}

\author{
Rita de Cássia Siqueira-Soares, Anderson Ricardo Soares, Angela Valderrama Parizotto, \\ Maria de Lourdes Lucio Ferrarese, and Osvaldo Ferrarese-Filho
}

Laboratory of Plant Biochemistry, Department of Biochemistry, University of Maringá, Av. Colombo 5790, 87020-900 Maringá, PR, Brazil

Correspondence should be addressed to Osvaldo Ferrarese-Filho; osferrarese@gmail.com

Received 2 September 2013; Accepted 2 October 2013

Academic Editors: H. P. Bais and M. Cresti

Copyright (c) 2013 Rita de Cássia Siqueira-Soares et al. This is an open access article distributed under the Creative Commons Attribution License, which permits unrestricted use, distribution, and reproduction in any medium, provided the original work is properly cited.

\begin{abstract}
L-3,4-Dihydroxyphenylalanine (L-DOPA) is a known allelochemical exuded from the roots of velvet bean (Mucuna pruriens L. Fabaceae). In the current work, we analyzed the effects of L-DOPA on the growth, the activities of phenylalanine ammonia-lyase $(\mathrm{PAL})$, tyrosine ammonia-lyase (TAL), and peroxidase (POD), and the contents of phenylalanine, tyrosine, and lignin in maize (Zea mays) roots. Three-day-old seedlings were cultivated in nutrient solution with or without 0.1 to $2.0 \mathrm{mM}$ L-DOPA in a growth chamber $\left(25^{\circ} \mathrm{C}\right.$, light/dark photoperiod of $12 / 12$, and photon flux density of $\left.280 \mu \mathrm{mol} \mathrm{m}^{-2} \mathrm{~s}^{-1}\right)$ for $24 \mathrm{~h}$. The results revealed that the growth (length and weight) of the roots, the PAL, TAL, and soluble and cell wall-bound POD activities decreased, while phenylalanine, tyrosine, and lignin contents increased after L-DOPA exposure. Together, these findings showed the susceptibility of maize to L-DOPA. In brief, these results suggest that the inhibition of PAL and TAL can accumulate phenylalanine and tyrosine, which contribute to enhanced lignin deposition in the cell wall followed by a reduction of maize root growth.
\end{abstract}

\section{Introduction}

Allelochemicals are found in many higher plants. These compounds can be regularly released into the environment by various mechanisms, such as leaching by rainwater, excretion or exudation from roots, and by the natural decay of parts of plants lying above or below the ground [1]. In contact with the rhizosphere or the bulk soil, allelochemicals may be absorbed by receptor plants and exert their action. Although allelochemicals play a relevant role in chemical plant-plant interactions, the primary mode of action has not been established for any of them. In general, they suppress seed germination, cause injury to root growth, and inhibit seedling growth. Moreover, they alter several physiological processes such as water and mineral uptake, foliar expansion, photosynthesis, membrane permeability, cell morphology, protein synthesis, cell respiration, and enzyme activity $[2,3]$.

Velvet bean (Mucuna pruriens L. Fabaceae) is an important plant species in tropical countries like India and other parts of Central and South America [4]. It has long been cultivated in tropical regions for intercropping with maize, sorghum, and millet and for providing benefits such as symbiotic nitrogen fixation, weed smothering, nutrient recycling, suppression of the nematode population, control of erosion, and soil improvement $[5,6]$. Many secondary compounds are produced by the seeds, leaves, and roots of velvet bean, but the main compound is the nonprotein amino acid L3,4-dihydroxyphenylalanine (L-DOPA). This allelochemical constitutes $0.5-1.5 \%$ of the fresh leaves weight [7] and 6-9\% of the dry seed weight [8]. The yield of fresh weight leaves and stems from plants ranges from 20 to $30 \mathrm{ton} \mathrm{ha}^{-1}$, and, as a consequence, velvet bean can add $100-450 \mathrm{~kg} \mathrm{ha}^{-1}$ of LDOPA to soils $[9,10]$. The concentration of L-DOPA released from velvet bean roots may reach $1 \mathrm{ppm}$ in water culture solution and $50 \mathrm{ppm}$ in the vicinity of roots [11], both of which are sufficient to affect the growth of neighboring plants by reducing seed germination and suppressing root growth $[7,10,12-15]$. However, the mechanism of action of L-DOPA is not well clarified in plants. 
L-DOPA is a precursor of many alkaloids, catecholamines, flavonoids, melanin, and phenylpropanoids in plants [16]. The phenylpropanoid pathway is one of the most important metabolic routes because it synthesizes phenolic compounds and many other secondary chemical agents, including lignin. Some enzymes of this metabolic pathway, such as phenylalanine ammonia-lyase (PAL), tyrosine ammonia-lyase (TAL), and peroxidase (POD), are associated with the synthesis and polymerization of monolignols and, consequently, with premature lignification $[17,18]$. We have demonstrated previously that soybean (Glycine max) seedlings had impaired root growth and increased lignin production after L-DOPA treatment [19]. However, no reports on the effects of exogenous L-DOPA on maize roots are available to date. In view of this open question, the purpose of work was to evaluate the effects of L-DOPA on maize root growth and the activities of some enzymes related to the phenylpropanoid pathway, such as PAL, TAL, and POD. The phenylalanine, tyrosine, and lignin levels also were evaluated.

\section{Materials and Methods}

2.1. General Procedures. Maize (Zea mays cv. IPR-114) seeds were surface-sterilized with $2 \%$ sodium hypochlorite for $5 \mathrm{~min}$, rinsed extensively with deionized water, and darkgerminated at $25^{\circ} \mathrm{C}$ on two sheets of moistened filter paper. Twenty-five 3-day-old seedlings of uniform size were supported by an adjustable acrylic plate and dipped into a $10 \times$ $16 \mathrm{~cm}$ glass container filled with $200 \mathrm{~mL}$ of half-strength Hoagland's solution ( $\mathrm{pH} 6.0$ ), with or without 0.1 to $2.0 \mathrm{mM}$ L-DOPA. All nutrient solutions were buffered with $67 \mathrm{mM}$ potassium phosphate buffer to eliminate the effects of very low $\mathrm{pH}$. The containers were kept in a growth chamber for $24 \mathrm{~h}$ at $25^{\circ} \mathrm{C}$, with a light/dark photoperiod of $12 / 12 \mathrm{~h}$ and a photon flux density of $280 \mu \mathrm{mol} \mathrm{m} \mathrm{m}^{-2} \mathrm{~s}^{-1}$. The roots were measured before incubation and at the end of the experiment, and the difference in length was calculated for all of the samples. The fresh root weight was determined immediately after incubation, and the dry weight was estimated after ovendrying at $80^{\circ} \mathrm{C}$ until a constant weight was achieved. L-DOPA was purchased from Sigma-Aldrich (St. Louis, MO, USA), and all other reagents used were of the purest grade available or of chromatographic grade.

2.2. Enzymatic Assays. PAL was extracted as described by Ferrarese et al. [20]. Fresh roots $(2 \mathrm{~g})$ were ground at $4^{\circ} \mathrm{C}$ in $0.1 \mathrm{M}$ sodium borate buffer $(\mathrm{pH} 8.8)$; the homogenate was centrifuged $(2,200 \times \mathrm{g}, 15 \mathrm{~min})$ and the supernatant was used as the enzyme preparation. The reaction mixture contained $100 \mu \mathrm{mol}$ sodium borate buffer, $\mathrm{pH} 8.7$, and a suitable amount of enzyme extract in a final volume of $1.5 \mathrm{~mL}$. The mixture was incubated at $40^{\circ} \mathrm{C}$ for $5 \mathrm{~min}$. To initiate the reaction, $15 \mu \mathrm{mol}$ of L-phenylalanine was added, and the reaction was stopped after $1 \mathrm{~h}$ by the addition of $50 \mu \mathrm{L}$ of $5 \mathrm{M} \mathrm{HCl}$. The sample was filtered through a $0.45 \mu \mathrm{m}$ disposable syringe filter and analyzed $(20 \mu \mathrm{L})$ in a high performance liquid chromatography (HPLC) system (Shimadzu, Tokyo, Japan). A reversephase Shimpack CLC-ODS column $(150 \mathrm{~mm} \times 4.6 \mathrm{~mm}$,
$5 \mu \mathrm{m}$ ) was used at $30^{\circ} \mathrm{C}$ with an equivalent precolumn. The mobile phase was $70 \%$ methanol $(\mathrm{v} / \mathrm{v})$, with a flow rate of $0.5 \mathrm{~mL} \mathrm{~min}^{-1}$ for an isocratic run of $10 \mathrm{~min}$. UV detection was performed at $275 \mathrm{~nm}$. The product of PAL, $t$-cinnamate, was identified by comparing its retention time with those of standard compounds. PAL activity is expressed as $\mu \mathrm{mol} t$ cinnamate $\mathrm{h}^{-1} \mathrm{~g}^{-1}$ fresh weight.

TAL was extracted as described by Khan et al. [21]. Fresh roots $(1 \mathrm{~g})$ were ground at $4^{\circ} \mathrm{C}$ in $2.5 \mathrm{~mL}$ of $50 \mathrm{mM}$ Tris$\mathrm{HCl} 0.1 \mathrm{M}$ buffer ( $\mathrm{pH}$ 8.5). The homogenate was centrifuged $(2,200 \times \mathrm{g}, 10 \mathrm{~min})$ and the supernatant was used as the enzyme preparation. The reaction mixture $(100 \mu \mathrm{mol}$ Tris$\mathrm{HCl}$ buffer, $\mathrm{pH} 8.5$, and a suitable amount of enzyme extract in a final volume of $0.95 \mathrm{~mL}$ ) was incubated at $40^{\circ} \mathrm{C}$ for $5 \mathrm{~min}$. To initiate the reaction, $5.5 \mu \mathrm{mol}$ of L-tyrosine was added, and the reaction was stopped after $1 \mathrm{~h}$ by the addition of $50 \mu \mathrm{L}$ of $5 \mathrm{M} \mathrm{HCl}$. The sample was filtered through a $0.45 \mu \mathrm{m}$ disposable syringe filter and analyzed $(20 \mu \mathrm{L})$ by HPLC as described earlier. The mobile phase was methanol:acetic acid $4 \%(30 \%: 70 \%)$, with a flow rate of $0.8 \mathrm{~mL} \mathrm{~min}^{-1}$ for an isocratic run of $10 \mathrm{~min}$. UV detection was carried out at $320 \mathrm{~nm}$. p-Coumarate, the product of TAL reaction, was identified by comparing its retention time with standard compounds. Parallel controls without L-tyrosine or with $p$ coumarate (added as an internal standard in the reaction mixture) were performed. TAL activity is expressed as $\mu \mathrm{mol}$ $p$-coumarate $\mathrm{h}^{-1} \mathrm{~g}^{-1}$ fresh weight.

For the POD assay, fresh roots $(0.5 \mathrm{~g})$ were ground in a mortar with $0.01 \mathrm{~g}$ of PVP and $5 \mathrm{~mL}$ of $67 \mathrm{mM}$ phosphate buffer ( $\mathrm{pH} 7.0)$. The extract was centrifuged $(2,200 \times \mathrm{g}, 5 \mathrm{~min})$, and the supernatant was used to determine the activity of soluble POD. The pellet was incubated in $1 \mathrm{M} \mathrm{NaCl}(2 \mathrm{~mL}$ for $1 \mathrm{~h}$ at $\left.4^{\circ} \mathrm{C}\right)$. The homogenate was centrifuged $(2,200 \times \mathrm{g}$, $5 \mathrm{~min}$ ), and the supernatant contained the cell wall (ionically) bound POD. The enzyme activities were determined according to methods described by dos Santos et al. [22]. The reaction mixture $(3 \mathrm{~mL})$ contained $25 \mathrm{mM}$ sodium phosphate buffer ( $\mathrm{pH}$ 6.8), $2.58 \mathrm{mM}$ guaiacol, and $10 \mathrm{mM} \mathrm{H}_{2} \mathrm{O}_{2}$. The reaction was initiated by the addition of the enzyme extract. The oxidation of guaiacol was followed for $5 \mathrm{~min}$ at $470 \mathrm{~nm}$, and the enzyme activity was calculated from the extinction coefficient $\left(25.5 \mathrm{mM}^{-1} \mathrm{~cm}^{-1}\right)$. POD activities are expressed as $\mu \mathrm{mol}$ tetraguaiacoquinone $\mathrm{min}^{-1} \mathrm{~g}^{-1}$ fresh weight.

2.3. Phenylalanine and Tyrosine Quantification. Samples (5.0 mg of dry root) that had been previously defatted were transferred to Pyrex ampoules $(10 \times 150 \mathrm{~mm})$ that had been pyrolyzed at $400^{\circ} \mathrm{C}$ for $8 \mathrm{~h}$. Next, $0.5 \mathrm{~mL}$ of aqueous $6 \mathrm{M}$ $\mathrm{HCl}$, which had been doubly distilled at $104^{\circ} \mathrm{C}$ and contained $0.1 \%$ phenol, was added to each sample. Vials were sealed under vacuum and placed in an oven at $110^{\circ} \mathrm{C}$ for $22 \mathrm{~h}$. After acid hydrolysis, the solution was dried using rotary evaporation and resuspended in $0.17 \mathrm{M}$ sodium citrate buffer ( $\mathrm{pH}$ 2.2) containing 15\% polyethylene glycol (PEG 400) and $0.4 \%$ thiodiglycol. Samples $(0.9 \mathrm{~mL})$ were loaded into a cation exchange column (Resin: PC 6A amino acid analysis resin pierce) and eluted by $\mathrm{pH}$ and ionic strength (short column $\mathrm{pH}$ 5.28, long column $\mathrm{pH} 3.25$, and additional $\mathrm{pH}$ 4.25). After 
chromatographic separation, the amino acids eluted from the column were reacted with ninhydrin in a boiling water bath $\left(100^{\circ} \mathrm{C}\right.$ for $\left.15 \mathrm{~min}\right)$, and the products of the reaction were detected colorimetrically at $570 \mathrm{~nm}$ [23]. The phenylalanine and tyrosine contents are expressed as $\mathrm{mg} \mathrm{g}^{-1}$ dry weight.

2.4. Lignin Quantification. After the incubation period, dry roots $(0.3 \mathrm{~g})$ were homogenized in $50 \mathrm{mM}$ potassium phosphate buffer $(7 \mathrm{~mL}, \mathrm{pH} 7.0)$ with a mortar and pestle and transferred into a centrifuge tube [24]. The pellet was centrifuged $(1,400 \times \mathrm{g}, 4 \mathrm{~min})$ and washed by successive stirring and centrifugation as follows: $2 \mathrm{x}$ with phosphate buffer $\mathrm{pH}$ $7.0(7 \mathrm{~mL}) ; 3 \mathrm{x}$ with $1 \%(\mathrm{v} / \mathrm{v})$ Triton $\mathrm{X}-100$ in $\mathrm{pH} 7.0$ buffer $(7 \mathrm{~mL}) ; 2 \mathrm{x}$ with $1 \mathrm{M} \mathrm{NaCl}$ in $\mathrm{pH} 7.0$ buffer $(7 \mathrm{~mL}) ; 2 \mathrm{x}$ with distilled water $(7 \mathrm{~mL})$; and $2 \mathrm{x}$ with acetone $(5 \mathrm{~mL})$. The pellet was dried in an oven $\left(60^{\circ} \mathrm{C}, 24 \mathrm{~h}\right)$ and cooled in a vacuum desiccator. The dry matter obtained was defined as a proteinfree cell wall fraction. Lignin content was determined by the acetyl bromide method [25]. Sample $(20 \mathrm{mg})$ of proteinfree cell wall fraction obtained earlier was placed into a screw-cap centrifuge tube containing $0.5 \mathrm{~mL}$ of $25 \%$ acetyl bromide (v/v in glacial acetic acid) and incubated at $70^{\circ} \mathrm{C}$ for $30 \mathrm{~min}$. After complete digestion, the samples were quickly cooled on ice and mixed with $0.9 \mathrm{~mL}$ of $2 \mathrm{M} \mathrm{NaOH}, 0.1 \mathrm{~mL}$ of $7.5 \mathrm{M}$ hydroxylamine- $\mathrm{HCl}$, and $2 \mathrm{~mL}$ of glacial acetic acid. After centrifugation $(1,400 \times \mathrm{g}, 5 \mathrm{~min})$, the absorbance of the supernatant was measured at $280 \mathrm{~nm}$. A standard curve with lignin (alkali, 2-hydroxy-propyl ether, Aldrich 37,096$7)$ was generated, and the absorptivity $(\varepsilon)$ value obtained was $16.4 \mathrm{~g}^{-1} \mathrm{~L} \mathrm{~cm}^{-1}$. The results are expressed as mg lignin $\mathrm{g}^{-1}$ cell wall.

2.5. Statistical Design. The experimental design was completely randomized, with each point on the plot representing one glass container of 25 seedlings. The data are expressed as the means of three to six independent experiments \pm SE. Significant differences were verified by one-way analysis of variance (ANOVA) using the GraphPad Prism package (Version 2.0, GraphPad Software Inc., USA, 1995). Differences between parameters were evaluated by the Dunnett's multiple comparison test, and $P$ values $<0.05$ were adopted as the minimum criterion for statistical significance.

\section{Results}

In comparison with the control, the root lengths were reduced by $26.9 \%$ and $52.9 \%$ for 1.0 and $2.0 \mathrm{mM}$ treatments, respectively (Table 1 ). The effects of the allelochemical were also evident for root weights, which significantly decreased by $11.1 \%$ and $25.6 \%$ (fresh weight) and $9.5 \%$ and $16.3 \%$ (dry weight) after exposure to 1.0 and $2.0 \mathrm{mM}$ when compared with the respective controls.

In agreement with the effects observed on root growth, the enzyme activity of seedlings treated with L-DOPA was also significantly different from those of controls. Roots exposed to L-DOPA significantly decreased PAL activities by $16.2 \%$ to $79 \%$ after treatment with 0.1 to $2.0 \mathrm{mM}$, respectively, in comparison with the control $\left(2.25 \pm 0.06 \mu \mathrm{mol} \mathrm{h}^{-1} \mathrm{~g}^{-1}\right.$

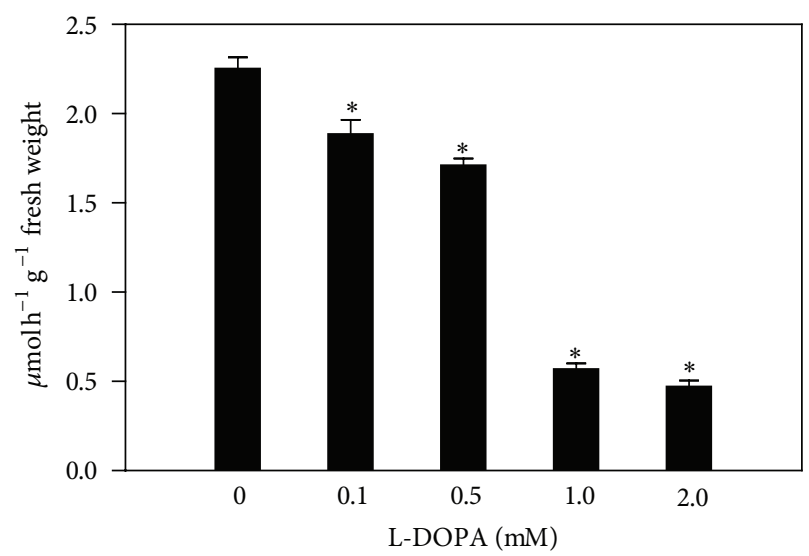

FIgURE 1: Effects of L-DOPA on phenylalanine ammonia-lyase (PAL). ${ }^{*}$ Values $(N=3 \pm \mathrm{SE}$ ) differ statistically (Dunnett's multiple comparison test) from control $(P<0.05)$.

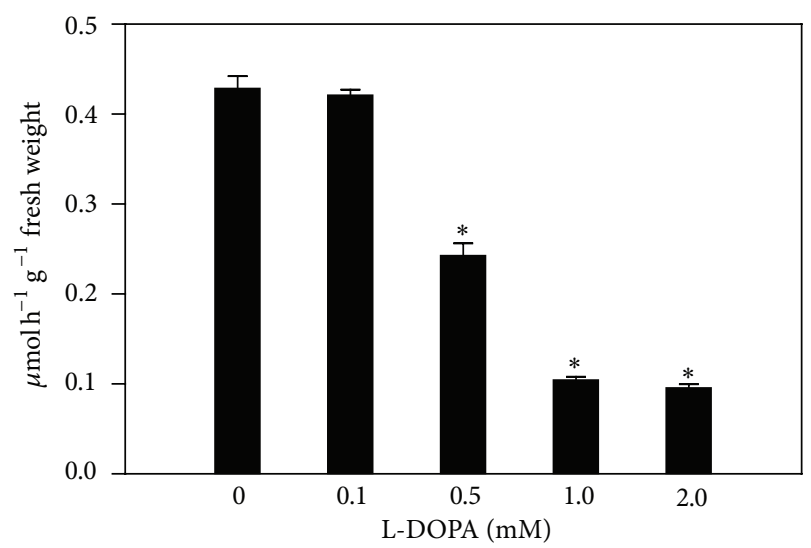

FIgURE 2: Effects of L-DOPA on tyrosine ammonia-lyase (TAL). ${ }^{*}$ Values $(N=3 \pm \mathrm{SE})$ differ statistically (Dunnett's multiple comparison test) from control $(P<0.05)$.

fresh weight) (Figure 1). The allelochemical also decreased TAL activities from 43.3 to $77.6 \%$ after 0.5 to $2.0 \mathrm{mM}$ treatments, compared with the control $\left(0.43 \pm 0.01 \mu \mathrm{mol} \mathrm{h}^{-1} \mathrm{~g}^{-1}\right.$ fresh weight) (Figure 2). The soluble POD activities were decreased by 9.8 and $15.2 \%$ for 1.0 and $2.0 \mathrm{mM}$ treatments, in comparison to the control $\left(8.05 \pm 0.38 \mu \mathrm{mol} \mathrm{h}^{-1} \mathrm{~g}^{-1}\right.$ fresh weight) (Figure 3(a)). On the other hand, the cell wall-bound POD activities were decreased after all L-DOPA treatments, that is, from 22.2 to $26.5 \%$, when compared to the control (1.03 $\pm 0.03 \mu \mathrm{mol} \mathrm{h}^{-1} \mathrm{~g}^{-1}$ fresh weight) (Figure 3(b)).

The lignin content increased from 15.3 to $25.7 \%$ after treatment with the two highest concentrations of L-DOPA, respectively, in comparison to the control $\left(159.4 \pm 3.01 \mathrm{mg} \mathrm{g}^{-1}\right.$ dry weight) (Figure 4). The results obtained after exposure of maize seedlings to L-DOPA revealed that the content of phenylalanine and tyrosine increased by $46 \%$ and $18.9 \%$, respectively, in comparison to the control (Table 2). 
TABLE 1: Changes in root length, root fresh and dry weights of maize seedlings treated with L-DOPA for $24 \mathrm{~h}$.

\begin{tabular}{|c|c|c|c|c|c|c|}
\hline L-DOPA (mM) & Root length $(\mathrm{cm})$ & $\%$ & Fresh weight (g) & $\%$ & Dry weight (g) & $\%$ \\
\hline $\begin{array}{l}0 \\
0.1\end{array}$ & $\begin{array}{c}3.38 \pm 0.032 \\
3.25 \pm 0.187^{\text {ns }}\end{array}$ & & $\begin{array}{c}2.15 \pm 0.052 \\
2.06 \pm 0.147^{\mathrm{ns}}\end{array}$ & & $\begin{array}{c}0.148 \pm 0.001 \\
0.145 \pm 0.004^{\mathrm{ns}}\end{array}$ & \\
\hline 0.5 & $2.98 \pm 0.140^{\mathrm{ns}}$ & & $1.96 \pm 0.020^{\mathrm{ns}}$ & & $0.138 \pm 0.002^{\mathrm{ns}}$ & \\
\hline 1.0 & $2.47 \pm 0.069^{*}$ & 26.9 & $1.89 \pm 0.083^{*}$ & 11.1 & $0.134 \pm 0.003^{*}$ & 9.5 \\
\hline 2.0 & $1.59 \pm 0.061^{*}$ & 52.9 & $1.68 \pm 0.044^{*}$ & 25.6 & $0.124 \pm 0.004^{*}$ & 16.32 \\
\hline
\end{tabular}

Means $(N=5 \pm \mathrm{SE})$ significantly smaller than the experiment control (Dunnett's multiple comparison test) are marked ${ }^{*}$.ns: not significant at 0.05 level. The symbol $\%$ represents inhibition of statistically significant means when compared to control $(0 \mathrm{mM})$.

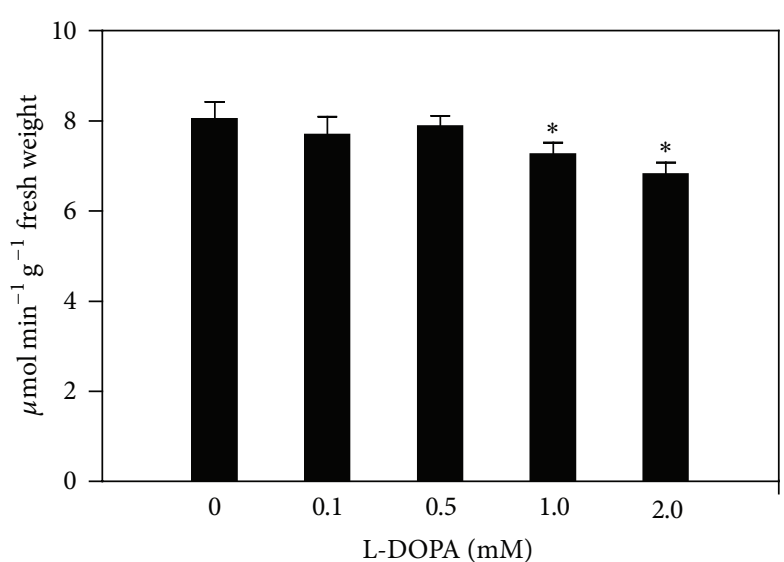

(a)

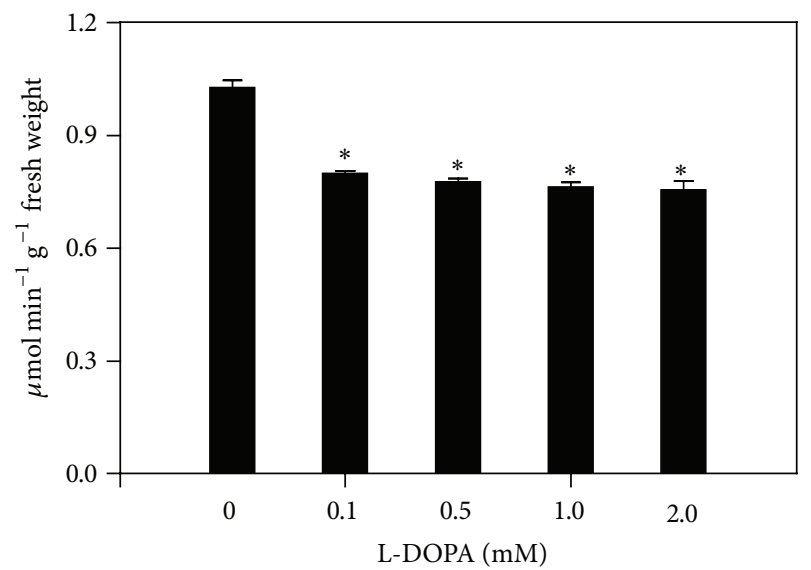

(b)

Figure 3: Effects of L-DOPA on soluble (a) and cell wall-bound (b) peroxidases (POD). ${ }^{*}$ Values $(N=5 \pm$ SE) differ statistically (Dunnett's multiple comparison test) from control $(P<0.05)$.

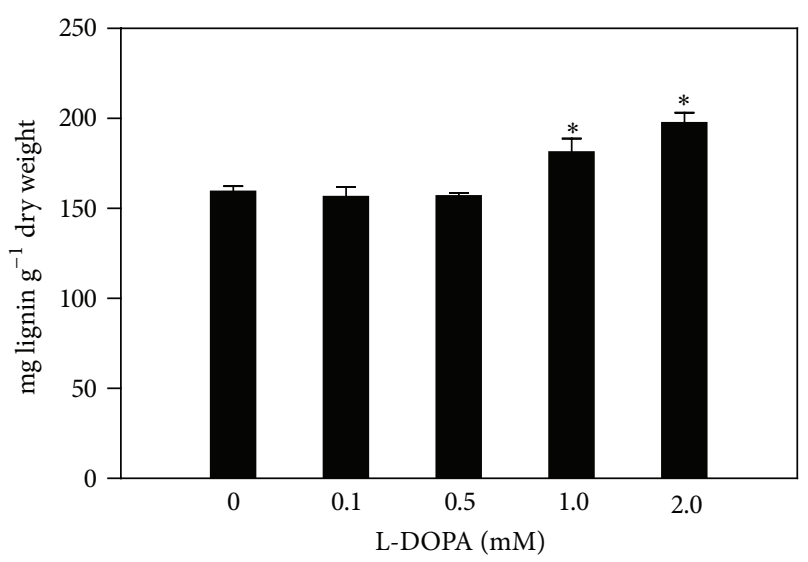

Figure 4: Effects of L-DOPA on lignin contents. ${ }^{*}$ Values $(N=$ $4 \pm$ SE) differ statistically (Dunnett's multiple comparison test) from control $(P<0.05)$.

\section{Discussion}

In the current work, we showed that the growth (length and weight) of maize roots was significantly affected by L-DOPA (Table 1), which is a feature common to the effects of different allelochemicals in plants $[2,3]$. The reduction of root growth by the action of L-DOPA at different concentrations has been described in several plant species [26-28] although some of
TABLE 2: Changes in the levels of tyrosine and phenylalanine of maize seedlings treated with L-DOPA for $24 \mathrm{~h}$.

\begin{tabular}{lcc}
\hline $\begin{array}{l}\text { L-DOPA } \\
(\mathrm{mM})\end{array}$ & $\begin{array}{c}\text { Tyrosine } \\
\left(\mu \mathrm{mol} \mathrm{g}^{-1} \text { fresh weight }\right)\end{array}$ & $\begin{array}{c}\text { Phenylalanine } \\
\left(\mu \mathrm{mol} \mathrm{g}^{-1} \text { fresh weight }\right)\end{array}$ \\
\hline 0 & $7.9 \pm 0.152$ & $2.18 \pm 0.033$ \\
0.5 & $9.4 \pm 0.115^{*}$ & $3.18 \pm 0.174^{*}$ \\
\hline
\end{tabular}

Means $(N=3 \pm \mathrm{SE})$ significantly smaller than the experiment control (Student's $t$ test) are marked*.

them were resistant to the allelochemical [13]. Since L-DOPA reduced the growth of maize roots (Table 1), its role as a potent allelochemical has been strengthened.

Decrease in root length has been related to the cell wall lignification induced by allelochemicals. In general, lignification stiffens the cell wall with concomitant increases in PAL and POD activities. In fact, increases of PAL activity correlate with reduction of root growth and lignin production in maize, cucumber, and soybean exposed to the action of phenylpropanoid allelochemicals [22, 29-31]. In addition, soluble and cell wall-bound POD activities increase concomitantly with lignin production in roots of maize [29], cucumber [30], and soybean $[22,32,33]$. With respect to LDOPA, Soares et al. [19] observed a reduced root length of soybean followed by increases in PAL and POD activities and lignin content. 
In contrast to the abovementioned reports, we have found that L-DOPA decreased the maize root growth and PAL, TAL, and soluble and cell wall-bound POD activities (Figures 1 to 3) but slightly increased the lignin content at high concentrations (Figure 4). It is not a bottleneck effect, however, because the apparent contradiction can be refuted by the complexity of the shikimate and phenylpropanoid pathways in plants. The shikimate pathway, which leads to the synthesis of aromatic amino acids such as phenylalanine and tyrosine, and the phenylpropanoid pathway towards the synthesis of lignin are clearly interconnected [18]. It is well known that lignin consists of $p$-hydroxyphenyl $(\mathrm{H})$, guaiacyl $(\mathrm{G})$, and syringyl ( $S$ ) monomers, which can vary between plant species and different tissues and localization of the cell wall [17, $34,35]$. In addition to these main units, unconventional monomers can be formed from $p$-coumarates, acetates, acylated hydroxycinnamyl alcohols, $p$-hydroxybenzoates, dihydrohydroxycinnamyl alcohols, and tyramine ferulate $[18,36$, 37]. Furthermore, Ralph et al. [38] suggested that the plants simply require a polymer with specific mechanical properties, and that the usual composition of lignin is not important. Due to these findings, it is not surprising that lignin can be maintained at a relatively constant level, even when enzymes involved in the synthesis of its precursors (PAL and TAL) and polymerization (POD) are suppressed or compromised. Such evidences can explain the slight increase of lignin content observed herein (Figure 4).

It has become clear from this study that L-DOPA increased the levels of phenylalanine and tyrosine in maize roots (Table 2). Some studies suggest that L-DOPA can be metabolized in these two amino acids. For example, Nakajima et al. [12] observed a significant accumulation of L-DOPA and free amino acids in the roots of cucumber in comparison to untreated plants. Also, enhanced levels of phenylalanine and tyrosine have been found in Echinochloa crus-galli, lettuce [26] and soybean [15] after L-DOPA treatments. According to the latter report, the accumulation of both amino acids can be a result of the detoxification of L-DOPA. Here, we believe that the inhibition of PAL and TAL (Figures 1 and 2) can also contribute to the accumulation of phenylalanine and tyrosine, followed by incorporation of these amino acids into the cell wall. Evidences support this hypothesis. Carpita [39] reported that sections excised from maize coleoptiles incorporated radioactivity from phenylalanine (40\%) and tyrosine (30\%) into structural components of the cell wall. Moreover, linkages of phenolic side-chains of tyrosine residues are directly involved in lignin deposition into the cell wall [40]. In addition, a tyrosine-rich cell wall protein has been specifically located in the secondary cell wall and can be involved in the lignin deposition [41]. Finally, McDougall et al. [42] observed that the presence of tyrosine residues increased the incorporation of monolignol coniferyl alcohol into ligninlike polymers.

\section{Conclusion}

If our hypothesis is correct, L-DOPA can be metabolized to phenylalanine and tyrosine in maize roots or, itself, can inhibit enzymes of the phenylpropanoid pathway, such as PAL and TAL, accumulating amino acids. A possible incorporation of phenylalanine and tyrosine into the cell wall can increase the presence of unconventional monomers followed by lignin deposition. As a consequence, the cell expansion is restricted and the root growth is reduced. To give a clear answer to this hypothesis, additional efforts are required to evaluate the structural characterization of the supposed unconventional lignin, including a more specific analysis of phenylalanine and tyrosine residues into the cell wall after L-DOPA treatments. This is the challenge faced by a new study that is currently in progress.

\section{Conflict of Interests}

The authors declare that they have no conflict of interests in the study.

\section{Acknowledgments}

Research was financially supported by the Brazilian Council for Scientific and Technological Development (CNPq). The authors kindly thank Aparecida M. D. Ramos and Fabiano Rodrigo de Assis for their technical assistance.

\section{References}

[1] E. L. Rice, Allelopathy, Academic Press, Orlando, Fla, USA, 1984.

[2] Inderjit, K. M. M. Dakshini, and F. A. Einhellig, Allelopathy Organisms, Processes, and Applications, American Chemical Society, Washington, DC, USA, 1995.

[3] T. L. Weir, S.-W. Park, and J. M. Vivanco, "Biochemical and physiological mechanisms mediated by allelochemicals," Current Opinion in Plant Biology, vol. 7, no. 4, pp. 472-479, 2004.

[4] A. P. Raina, J. B. Tomar, and M. Dutta, "Variability in Mucuna pruriens L. germplasm for L-Dopa, an anti parkinsonian agent," Genetic Resources and Crop Evolution, vol. 59, pp. 1-6, 2012.

[5] G. Tarawali, V. M. Manyong, R. J. Carsky, P. V. Vissoh, P. OseiBonsu, and M. Galiba, "Adoption of improved fallows in West Africa: lessons from mucuna and stylo case studies," Agroforestry Systems, vol. 47, no. 1-3, pp. 93-122, 1999.

[6] R. Vargas-Ayala, R. Rodríguez-Kábana, G. Morgan-Jones, J. A. McInroy, and J. W. Kloepper, "Shifts in soil microflora induced by velvetbean (Mucuna deeringiana) in cropping systems to control root-knot nematodes," Biological Control, vol. 17, no. 1, pp. 11-22, 2000.

[7] Y. Fujii, T. Shibuya, and T. Yasuda, "L-3,4-dihydroxyphenylalanine as an allelochemical candidate from Mucuna pruriens (L.) DC. var. utilis," Agricultural and Biological Chemistry, vol. 55, pp. 617-618, 1991.

[8] S. S. Rehr, D. H. Janzen, and P. P. Feeny, "L-dopa in legume seeds: a chemical barrier to insect attack," Science, vol. 181, no. 4094, pp. 81-82, 1973.

[9] C. A. H. Chou, G. R. Waller, and C. Reinhardt, Biodiversity and Allelopathy: from Organisms to Ecosystems in the Pacific, Academia Sinica, Taipei, Taiwan, 1999.

[10] A. Golisz, M. Sugano, S. Hiradate, and Y. Fujii, "Microarray analysis of Arabidopsis plants in response to allelochemical LDOPA," Planta, vol. 233, no. 2, pp. 231-240, 2011. 
[11] E. Nishihara, M. M. Parvez, H. Araya, S. Kawashima, and Y. Fujii, "L-3-(3,4-Dihydroxyphenyl)alanine (L-DOPA), an allelochemical exuded from velvetbean (Mucuna pruriens) roots," Plant Growth Regulation, vol. 45, no. 2, pp. 113-120, 2005.

[12] N. Nakajima, S. Hiradate, and Y. Fujii, "Characteristics of growth inhibitory effect of L-3,4-dihydroxyphenylalanine (LDOPA) on cucumber seedlings," Journal of Weed Science and Technology, vol. 44, pp. 132-138, 1999.

[13] E. Nishihara, M. M. Parvez, H. Araya, and Y. Fujii, "Germination growth response of different plant species to the allelochemical L-3,4-dihydroxyphenylalanine (L-DOPA)," Plant Growth Regulation, vol. 42, no. 2, pp. 181-189, 2004.

[14] M. Hachinohe and H. Matsumoto, "Involvement of reactive oxygen species generated from melanin synthesis pathway in phytotoxicty of L-DOPA," Journal of Chemical Ecology, vol. 31, no. 2, pp. 237-246, 2005.

[15] A. R. Soares, R. C. Siqueira-Soares, V. H. Salvador, M. L. L. Ferrarese, and O. Ferrarese-Filho, "The effects of L-DOPA on root growth, lignification and enzyme activity in soybean seedlings," Acta Physiologiae Plantarum, vol. 34, pp. 1811-1817, 2012.

[16] K. Hahlbrock and D. Scheel, "Physiological and molecular biology of phenylpropanoid metabolism," Annual Review of Plant Physiology and Plant Molecular Biology, vol. 40, pp. 347-369, 1989.

[17] W. Boerjan, J. Ralph, and M. Baucher, "Lignin biosynthesis," Annual Review of Plant Biology, vol. 54, pp. 519-546, 2003.

[18] R. Vanholme, K. Morreel, C. Darrah et al., "Metabolic engineering of novel lignin in biomass crops," New Phytologist, vol. 196, pp. $978-1000,2012$.

[19] A. R. Soares, M. L. L. Ferrarese, R. C. Siqueira, F. M. L. Z. Böhm, and O. Ferrarese-Filho, "L-DOPA increases lignification associated with Glycine max root growth-inhibition," Journal of Chemical Ecology, vol. 33, no. 2, pp. 265-275, 2007.

[20] M. L. L. Ferrarese, J. D. Rodrigues, and O. Ferrarese-Filho, "Phenylalanine ammonia-lyase activity in soybean roots extract measured by reverse-phase high performance liquid chromatography," Plant Biology, vol. 2, no. 2, pp. 152-153, 2000.

[21] W. Khan, B. Prithiviraj, and D. L. Smith, "Chitosan and chitin oligomers increase phenylalanine ammonia-lyase and tyrosine ammonia-lyase activities in soybean leaves," Journal of Plant Physiology, vol. 160, no. 8, pp. 859-863, 2003.

[22] W. D. dos Santos, M. L. L. Ferrarese, A. Finger, A. C. N. Teixeira, and O. Ferrarese-Filho, "Lignification and related enzymes in Glycine max root growth-inhibition by ferulic acid," Journal of Chemical Ecology, vol. 30, no. 6, pp. 1203-1212, 2004.

[23] S. Moore, D. H. Spackman, and W. H. Stein, "Chromatography of amino acid on sulfonated polystyrene resins," Analytical Chemistry, vol. 30, no. 7, pp. 1185-1190, 1958.

[24] M. L. L. Ferrarese, A. Zottis, and O. Ferrarese-Filho, "Proteinfree lignin quantification in soybean (Glycine max) roots," Biologia, vol. 57, no. 4, pp. 541-543, 2002.

[25] R. D. Hatfield, J. Grabber, J. Ralph, and K. Brei, "Using the acetyl bromide assay to determine lignin concentrations in herbaceous plants: some cautionary notes," Journal of Agricultural and Food Chemistry, vol. 47, no. 2, pp. 628-632, 1999.

[26] M. Hachinohe, Y. Sunohara, and H. Matsumoto, "Absorption, translocation and metabolism of L-DOPA in barnyardgrass and lettuce: their involvement in species-selective phytotoxic action," Plant Growth Regulation, vol. 43, no. 3, pp. 237-243, 2004.
[27] A. R. Soares, M. L. L. Ferrarese, R. C. Siqueira-Soares, R. Marchiosi, A. Finger-Teixeira, and O. Ferrarese-Filho, "The allelochemical L-DOPA increases melanin production and reduces reactive oxygen species in soybean roots," Journal of Chemical Ecology, vol. 37, no. 8, pp. 891-898, 2011.

[28] M. N. Mushtaq, Y. Sunohara, and H. Matsumoto, "Bioactive L-DOPA induced quinoprotein formation to inhibit root growth of cucumber seedlings," Journal of Pesticide Science, vol. 38, pp. 68-73, 2013.

[29] S. Rama Devi and M. N. V. Prasad, "Ferulic acid mediated changes in oxidative enzymes of maize seedlings: implications in growth," Biologia Plantarum, vol. 38, no. 3, pp. 387-395, 1996.

[30] B. Politycka, "Ethylene-dependent activity of phenylalanine ammonia-lyase and lignin formation in cucumber roots exposed to phenolic allelochemicals," Acta Societatis Botanicorum Poloniae, vol. 68, no. 2, pp. 123-127, 1999.

[31] V. Herrig, M. L. L. Ferrarese, L. S. Suzuki, J. D. Rodrigues, and O. Ferrarese-Filho, "Peroxidase and phenylalanine ammonialyase activities, phenolic acid contents, and allelochemicalsinhibited root growth of soybean," Biological Research, vol. 35, no. 1, pp. 59-66, 2002.

[32] D. I. L. Zanardo, R. B. Lima, M. L. L. Ferrarese, G. A. Bubna, and O. Ferrarese-Filho, "Soybean root growth inhibition and lignification induced by p-coumaric acid," Environmental and Experimental Botany, vol. 66, no. 1, pp. 25-30, 2009.

[33] G. A. Bubna, R. B. Lima, D. Y. L. Zanardo, W. D. dos Santos, M. L. L. Ferrarese, and O. Ferrarese-Filho, "Exogenous caffeic acid inhibits the growth and enhances the lignification of the roots of soybean (Glycine max)," Journal of Plant Physiology, vol. 168, no. 14, pp. 1627-1633, 2011.

[34] E. O. S. Saliba, N. M. Rodrigues, S. A. L. Morais, and D. PilóVeloso, "Ligninas: métodos de obtenção e caracterização química," Ciência Rural, vol. 31, pp. 917-928, 2001.

[35] J. Rodrigues, J. Graça, and H. Pereira, "Influence of tree eccentric growth on syringyl/guaiacyl ratio in Eucalyptus globulus wood lignin assessed by analytical pyrolysis," Journal of Analytical and Applied Pyrolysis, vol. 58-59, pp. 481-489, 2001.

[36] R. W. Whetten, J. J. MacKay, and R. R. Sederoff, "Recent advances in understanding lignin biosynthesis," Annual Review of Plant Biology, vol. 49, pp. 585-609, 1998.

[37] R. R. Sederoff, J. J. MacKay, J. Ralph, and R. D. Hatfield, "Unexpected variation in lignin," Current Opinion in Plant Biology, vol. 2, no. 2, pp. 145-152, 1999.

[38] J. Ralph, J. J. MacKay, R. D. Hatfield, D. M. O’Malley, R. W. Whetten, and R. R. Sederoff, "Abnormal lignin in a loblolly pine mutant," Science, vol. 277, no. 5323, pp. 235-239, 1997.

[39] N. C. Carpita, "Incorporation of proline and aromatic amino acids into cell walls of maize coleoptiles," Plant Physiology, vol. 80, pp. 660-666, 1986.

[40] B. Keller, N. Sauer, and C. J. Lamb, "Glycine-rich cell wall proteins in bean: gene structure and association of the protein with the vascular system," The EMBO Journal, vol. 7, no. 12, pp. 3625-3633, 1988.

[41] C. Domingo, M. D. Gomez, L. Canas, J. Hernandez-Yago, V. Conejero, and P. Vera, "A novel extracellular matrix protein from tomato associated with lignified secondary cell walls," Plant Cell, vol. 6, no. 8, pp. 1035-1047, 1994.

[42] G. J. McDougall, D. Stewart, and I. M. Morrison, "Tyrosine residues enhance cross-linking of synthetic proteins into ligninlike dehydrogenation products," Phytochemistry, vol. 41, no. 1, pp. 43-47, 1996. 

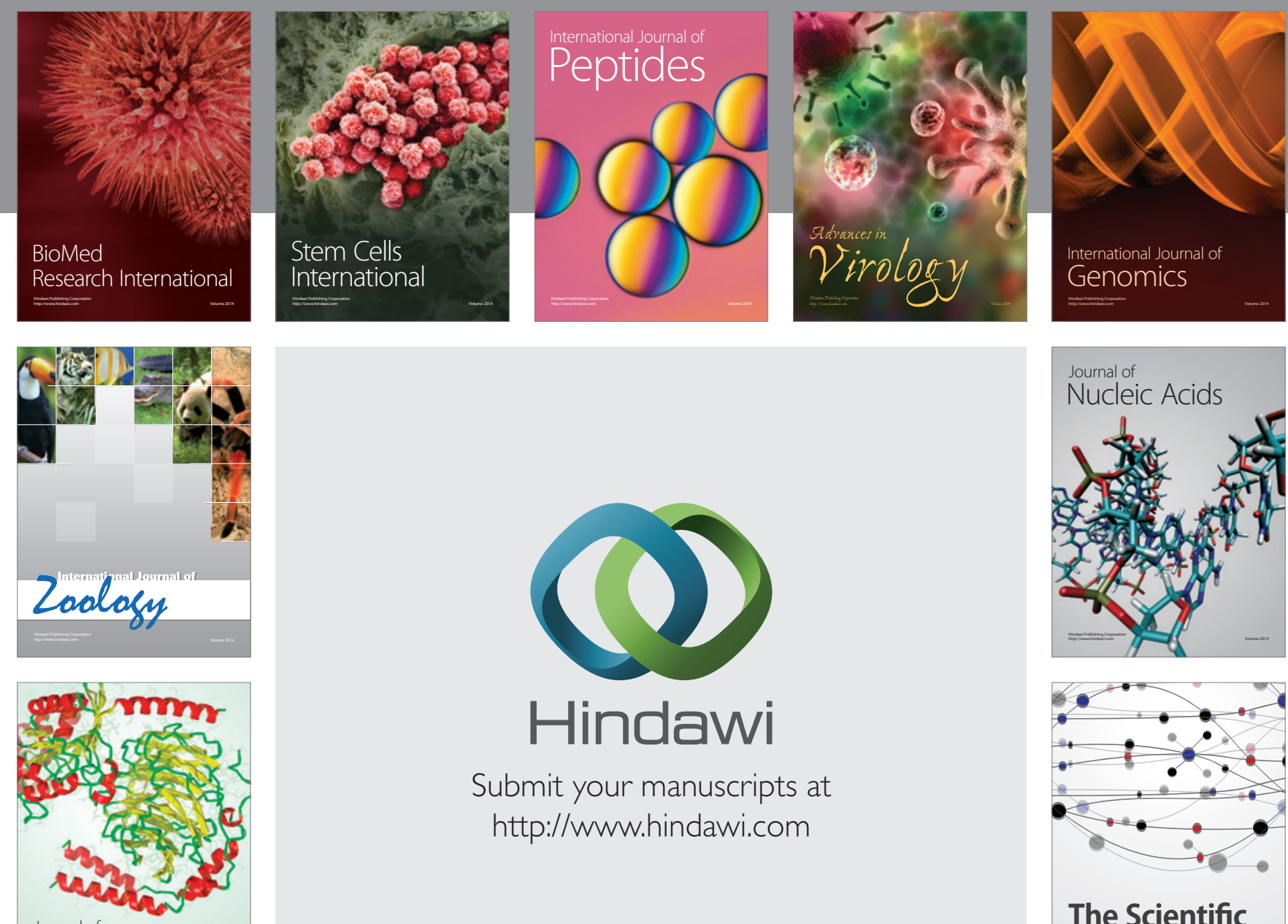

Submit your manuscripts at

http://www.hindawi.com

Journal of
Signal Transduction
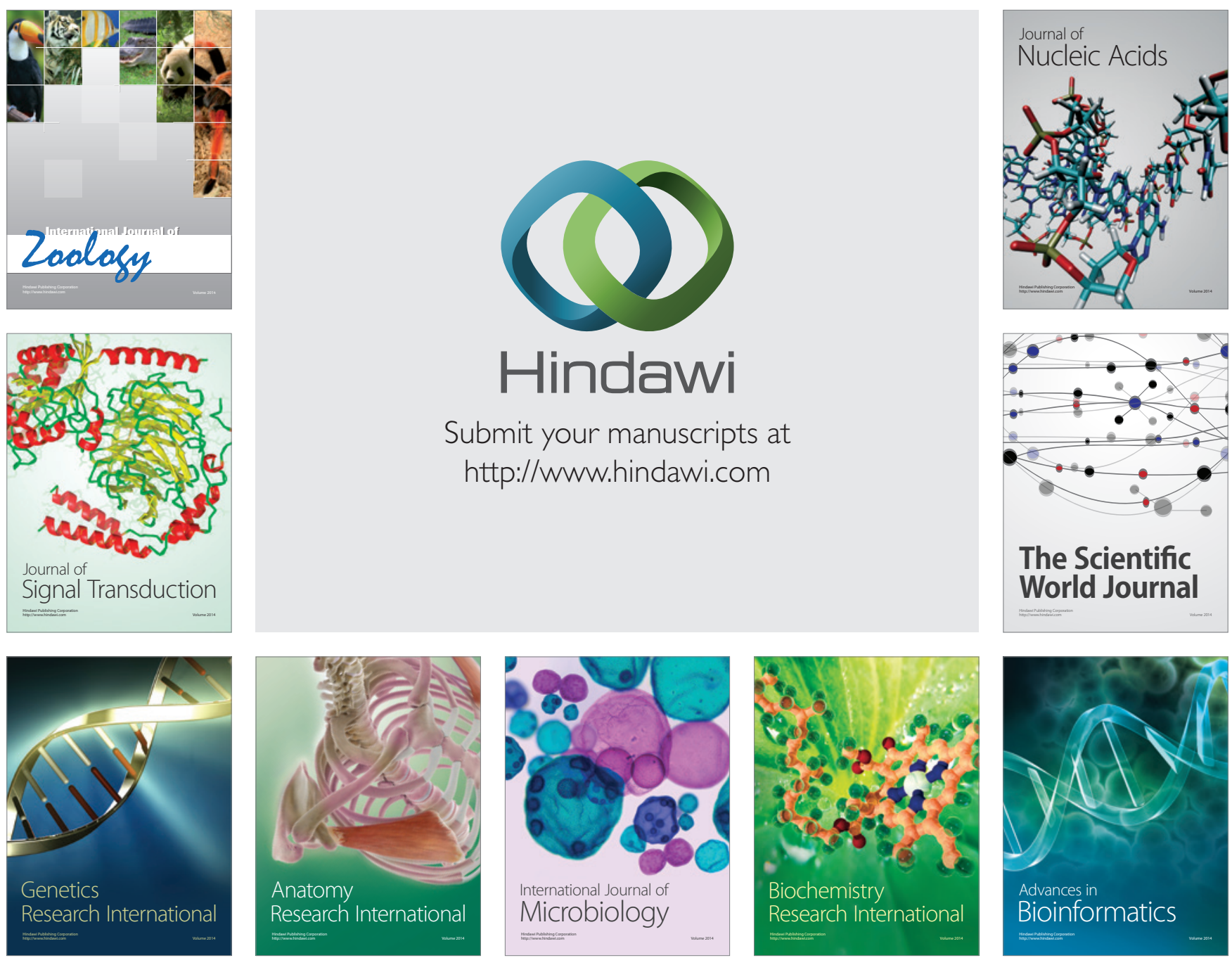

The Scientific World Journal
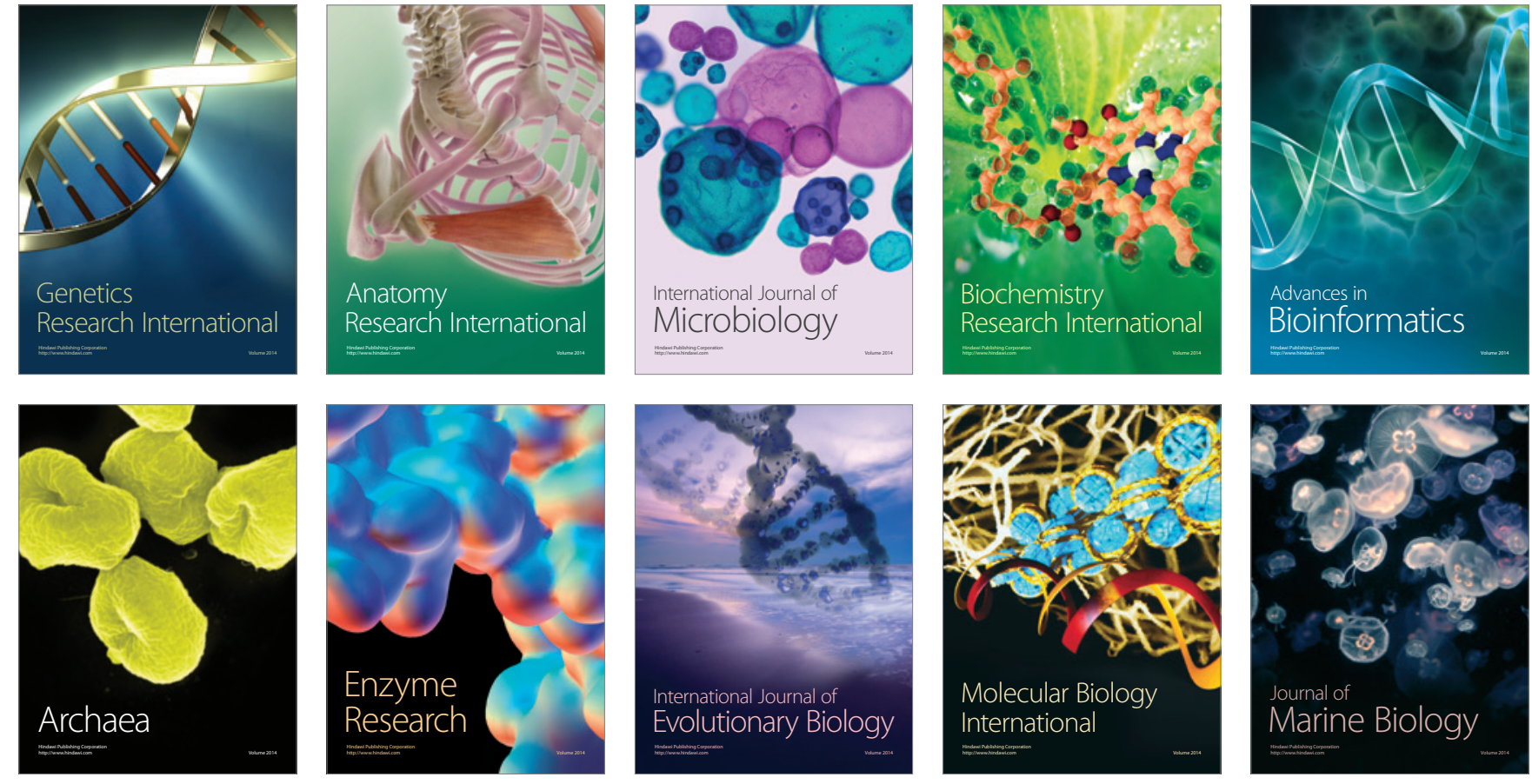